\title{
Job Satisfaction Analysis Through Supervision, Motivation and Organizational Culture
}

\author{
Martin $^{1}$ \\ ${ }^{I}$ Politeknik Unggul LP3M, Jl. Iskandar Muda No.3CDEF, Merdeka, Kec. Medan Baru, Kota Medan, Sumatera Utara 20156Address, \\ City and Postcode, Country
}

\section{ARTICLE INFO}

AIJ use only:

Received date : 01 June 2020

Revised date : 20 June 2020

Accepted date : 01 July 2020

\section{Keywords:}

Supervision

Motivation

Organizational Cultre

Jobs Sastisfaction

\begin{abstract}
A B S T R A C T
Main objective of this research is is to find out the effect of motivation and organizational culture to the job satisfaction are affecting both partially and simultaneously on Budisatrya Institution. Its research using cause and effect approach which measured the effect of independent variable to dependent variable. The population of its research are 97 the teachers of Budisatrya Institution as respondent. The data of the research are from questionnaire with Likert scale that were distributed and answered by the respondent. Double linear regression analysis is using of its research. The results show that all independent variable are positively and significantly affected to the job satisfaction. Supervision,motivation, and organizational culture are affecting job satisfaction,and dominant variable is supervision that Budisatrya do to their teachers.
\end{abstract}

\section{INTRODUCTION}

Employee existence in some organization, including in educational organization is important matters that influencing the succes and quality of organization. The accomplishing of organizatin objection is depend on how to manage their employee and govern it. Employee is a personel that operate some activites that accomplish organizational objection.employee is a important matter in some organization (Dhona, 2015).

Human resources is an improtant thing in some organization. Because of it, quality of human resources as employee in operational serve in some organization is a determinant matter. The strategyto obtain a good human resources which suit to the organization objective is needed in order to improving human resources quality and accomplishing organizational objective. Human resources management is giving previlige to

\footnotetext{
* Corresponding author.

E-mail address: m4rt1n.myrafa@gmail.com

Article with open access under license
}

encourage, distribute and maintain the employee in order to work with organizational objection (Dotulong, 2015).

Budisatrya Institution is one of the private school in Medan Tembung, Indonesia. Budisatrya is focused in educational service, and it's still providing the worth quality of education which are expected by the people and Indonesian nation also. School is a place where someone get the knowledge, and it also a place for someone to get some character building on it. Headmaster or Institution chief have responsibilities to maintain quality of it organization. so that its implicate many person to accomplish that objective. and the teacher of Budisatrya is an important things that are directly connect with the student.

Job satisfaction for the teachers is an important thing that the institution have to know, the satisfaction is reflected from the teachers passion for teaching and its liveliness on the school activities .The jobs satisfaction have an important meaning for an organization when an employee is satisfied with his job,it makes an positive effect to others, low of absenteeism level, get some promotion, loyalty of 
the employee and long lifeliness of employee duration (Siagian, 2015).

Supervision is a factor that affecting teachers. Supervision system is an effort to evaluate teachers during their duties. With this system, it can be expected that institution to handle and evaluate and informed the institution board about teachers for making decisions. According to (T. Hani Handoko, 2012)supervision have unfriendly meanings. Supervision is consider threats of freedom and privacy of the employee. While the employee need an apropriate system that help the organization accomplish their objections. It related to make some suitable activites and been planned. In order to make the employee do their jobs based on regulation and standard that organization set for. And reducing fraud and error during do their works. On the real implementation, supervision expected have similarities between method, procedure and technique, and it also have to effective and efficient. In order create good condition and good environment of workspace. And support supervision become a common thing to do in some organization. Human resources is key of succes for all development fields. Previous research are completely done by (Subhan, 2017) (Dhona, 2015) (Walangitan, 2017) tells that better supervision it can make job satisfaction is increasing.

Motivation is affecting the job satisfaction, motivation comes from the insider cause that make employee beeing motivated. Usually, employee work with their capabilities and efforts in order to get a promotion and fixed position in the organization. Otherwise when they get what they want, they become lazier and unmotivated to do their job. Motivation, passion, and optimum result have linear formed . In other words, giving a good motivation, so that increasing the work results and according to the standard. Passion of work is implemented by optimization of work result with the organization standard, increasing level of presence and punctuality of work. (Dotulong, 2015) (Lumanauw, 2011) (Maramis, 2013) (Nasib, 2019) tells that motivation inside the employee is increasing jobs satisfaction.

Organizational culture is also important factor that affecting job satisfaction,when someone work appropriate with their desire and reliable valuation system, more higher level of satisfaction is fullfilled, and vice versa. An effort to fixed an organizational culture is a serious way for an organization to increasing employee performance. The objcetion of it to make all member of the organization obey and guided by valuation system and ethic that be obtained on the organization. Previous result by (Subhan, 2017) (Maramis, 2013) (Uhing, 2018) (Adnyani, 2017) (Nasib; Ratih Amelia, 2018) tells that organizational culture is increasing job satisfaction

\section{METHOD}

The approaching of its research is a causal research, assosiative research is a research that discover relation and pattern between to variable or more. With this research, it can be built a theory which can define, forecast and control the phenomenon (Rusiadi, Subiantora, \& Hidayat, 2017). Population and sample of its research is 97 teacher of BudiSatrya senior high school and vocational high school. Determination tehcnique is using saturated sample, when sample is less than 100 respondent, all of the respondent can be the sample (Sugiyono, 2014). The sample of this research were 97, so all of the respondent are sample, the collection of data is using questionnaire with Likert scale and using Double lineary regression analysis.

\section{RESULTS AND DISCUSSION}

\section{Double Lineary Regression Analysis}

According to the table below, it can be concluded that the resultof double lineary regression analysis are as follow:

1. In this model, a constant value is 2,247 listed, it means if independent variabel assume as zero, averagely outsider variable of the model still increasing the jobs satisfaction of 2,247. In the other words, if motivation, supervision, and organizational culture are not increased, the job satisfaction is still 2,247 denomination.

2. Coeficient regression in this research $b_{1}$ is 0,519 denomination, it means if supervision increasing in one denomination, it showed that the job satisfaction increasing 0,519 denomination.

3. Coeficient regression $b_{2}$ in this research is 0,269 denomination, it means that motivation is 0,269 denomination, it showed when motivation is increased 0,269 denomination, job satisfaction is also increased 0,269 denomination.

4. Coeficient regression $b_{3}$ in this research is 0,249 denomination, it means that organizational culture is 0,249 denomination, it showed that organizational culture raised one denomination, so that job satisfaction is raised 0,249 denomination. 


\section{Hypotesis Test}

\section{t Test (Partially)}

1. Significant value for supervision $(0,000)$ is smaller than $5 \%$ of alpha $(0,05)$ or $\mathrm{t}_{\text {count }}$ $=5,891>\mathrm{t}_{\text {table }}=1,985 \quad(\mathrm{n}-\mathrm{k}=97-4=93)$. According to the result, $\mathrm{H}_{0}$ is rejected and accept $\mathrm{H}_{\mathrm{a}}$ for supervision variable. And partially, supervision is positively and significantly affected job satisfaction on Budisatrya Institution.

2. Significant value for motivation $(0,001)$ is smaller than $5 \%$ of alpha $(0,05)$ or $t_{\text {count }}$ $=3,406>\mathrm{t}_{\text {table }}=1,985 \quad(\mathrm{n}-\mathrm{k}=97-4=93)$. According to the result, $\mathrm{H}_{0}$ is rejected and accept $\mathrm{H}_{\mathrm{a}}$ for motivation variable And partially, motivation is positively and significantly affected job satisfaction on Budisatrya Institution.

3. Significant value for organizational culture $(0,006)$ is smaller than $5 \%$ of alpha $(0,05)$ or $\mathrm{t}_{\text {count }}=2,389>\mathrm{t}_{\text {table }}=1,985 \quad(\mathrm{n}-\mathrm{k}=97-4=93)$. According to the result, $\mathrm{H}_{0}$ is rejected and accept $\mathrm{H}_{\mathrm{a}}$ for organizational culture. And partially, organizational culture is positively and significantly affected job satisfaction on Budisatrya Institution.

\section{F Test (Simultaneouly)}

From the regression test on this research, be discovered that significant value 0,000 .the terms of $\mathrm{F}$ value is smaller than $5 \%$ or 0,05 or $\mathrm{F}_{\text {count }}=32,994>\mathrm{F}_{\text {table }}=2,70(\mathrm{df} 1=\mathrm{k}-1=4-$ $1=3)$, while (df2 $=\mathrm{n}-\mathrm{k}(97-4=93)$. It can be conclude that all independent variable which are supervision, motivation, organizational culture are significantly affecting job satisfaction on Budisatrya Institution.

\section{Determinant Coeficient}

Regression correlation value is 0,886 , it means that at the same time, supervision, motivation, organizational culture have a strong distribution of contribution level. Adjusted R square value is $0,778(77,8 \%)$. It means that $77,8 \%$ of various dependent variable which are supervision, motivation, organizational culture affecting job satisfaction on Budisatrya Institution. And $22,8 \%$ are afffected by the other outsider model variable.
The effect of supervision to Job Satisfaction.

The result showed that supervision positively and significantly affecting job satisfaction on Budisatrya Institution. Where supervision $(0,000)$ is smaller than $5 \%$ of alpha $(0,05)$ or $\mathrm{t}_{\text {count }}=5,891>\mathrm{t}_{\text {table }}=1,985 \quad(\mathrm{n}-\mathrm{k}=97-4=93)$. According to the result, $\mathrm{H}_{0}$ is rejected and accept $\mathrm{H}_{\mathrm{a}}$ for supervision variable. This result is also supported the previous research that (Dotulong, 2015) (Lumanauw, 2011) (Maramis, 2013) (Nasib, 2019) tells that motivation inside the employee is increasing jobs satisfaction.

\section{The effect of Organizational Culture to Job Satisfaction.}

The result showed that orrganizational culture is positively and significantly affecting job satisfaction on Budisatrya Institution. Where organizational culture $(0,006)$ is smaller than $5 \%$ of alpha $(0,05)$ or $\mathrm{t}_{\text {count }}=2,389>$ $\mathrm{t}_{\text {table }}=1,985(\mathrm{n}-\mathrm{k}=97-4=93)$. According to the result, $\mathrm{H}_{0}$ is rejected and accept $\mathrm{H}_{\mathrm{a}}$ for organizational culture. This result is also supported the previous research by (Nasib; Ratih Amelia, 2018) (Uhing, 2018) (Maramis, 2013) (Pebri, 2020) (Ballian, 2020) (Napitupulu, 2020) tells that organizational culture is increasing job satisfaction.

\section{CONCLUSION}

Simultaneously all of the independent variable whic are supervision, motivation, organizational culture are positively and significantly afffecting job satisfaction on Budisatrya Institution. Dominant variable is supervision that Budisatrya do to get information about the teacher during their duties.

Partially, motivation is positively and significantly affecting job satisfaction on Budisatrya Institution. Motivation have to be keep by their institution board in order to increase their loyalty, performance and dedication. It can be done by giving the employee some benefit like scholarship, family gathering or vacation and health insurance for the employee.

Partially, suervision and organizational culture are positively and significantly affecting job satisfaction on Budisatrya Institution. Which are the culture and supervision are well run. The institution treat every employee like family. It have to be keep and increasing in the future days. It makes all of the employee fell being love and make them have a strong connection to Budisatrya Institution 


\section{REFERENCES}

1. Adnyani, I. G. A. E. S. I. G. A. D. (2017). Pengaruh Gaya Kepemimpinan Dan Budaya Organisasi Terhadap Kepuasan Kerja Karyawan. E-Jurnal Manajemen Unud, 6(12), 6592-6619.

2. Ballian, W. H. H. N. M. S. S. H. (2020). Analysis of Reward, Work Environment, Job Promotion And Supporting Facilities Towards Job Satisfaction. International Journal of Innovative Science and Research Technology, 5(4), 167-171.

3. Dhona, D. E. E. (2015). Pengaruh Pengawasan yang Dilakukan Pimpinan Dengan Kepuasan Kerja Pegawai Pada Kantor Badan Kepegawaian Daera Provinsi Sumatera Barat. JUrnal Bahana Manajemen Pendidikan, 3(1), 291-759.

https://doi.org/10.1017/CBO9781107415324.0 $\underline{04}$

4. Dotulong, M. D. . L. L. O. . (2015). Pengaruh Motivasi, Disiplin, dan Lingkungan Kerja Terhadap Kepuasan Kerja Karyawan Pada PT. Bank SULUT Cabang Airmadidi. Jurnal EMBA, 3(1), 74-85.

5. Lumanauw, N. E. F. B. T. B. (2011). Pengrauh Motivasi Kerja, Disiplin Dan Insentif Terhadap Kepuasan Kerja Karyawan Pada RSUP Dr. R. D. Kandou Malalayang. Jurnal EMBA, 5(1), 110.

6. Maramis, E. (2013). Kepemimpinan, Budaya Organisasi, Dan Motivasi Pengaruhnya Terhadap Kinerja Karyawan Pada PT. Bank Tabungan Negara (Persero) Cabang Manado. Jurnal EMBA, 1(4), 955-964.

7. Napitupulu, I. L. A. R. P. E. E. S. S. D. Z. (2020). Analysis of Perceived Organizational Support in Moderating Relationship of Employee Readiness to Employee Commitments in Change Organizations in
Regional Companies. International Journal of Innovative Science and Research Technology, 5(4).

8. Nasib; Ratih Amelia. (2018). Pengaruh Budaya Organisasi Dan Lingkungan Kerja Terhadap Kinerja Karyawan Di PT. Perkebunan Nisantara IV Medan. In Prosiding Seminar Nasional SINASTEKMAPAN (Vol. I, pp. 186197).

9. Nasib, S. C. S. A. Y. (2019). Optimalisasi Prestasi Kerja Melalui Peningkatan Disiplin, Motivasi Dan Lingkungan Kerja Pada PT. Vamrer Jaya Abadi Medan. In The 2nd Interntional Conference on Politics of Islamic Development (pp. 192-201).

10. Pebri, N. A. R. S. S. P. (2020). Performance Optimization By Compensation, Organizational Commitmentand Job Promotion Towards Job Satisfaction. International Journal of Business and Management Invention IJBMI, 9(4), 37-42.

11. Siagian, S. (2015). Teori dan Praktek Kepemimpinan. Jakarta: Rieneka Cipta.

12. Subhan. (2017). Pengaruh Pengawasan Dan Iklim Organisasi Terhadap Kepuasan Kerja Dan Disiplin Kerja Pada Polres Semarang. Jurnal Bingkai Manajemen, 9(20), 254-269.

13. T. Hani Handoko. (2012). Manajemen Personalia dan Sumber Daya Manusia. Yogyakarta: BPFE.

14. Uhing, M. S. B. T. Y. (2018). Pengaruh Budaya Organisasi Dan Stres Kerja Terhadap Kepuasan Kerja Dan Produktivitas Kerja Karyawan PT. Air Manado. Jurnal EMBA, 6(4), 2408-2418.

15. Walangitan, M. L. B. T. M. D. (2017). Pengaruh Pengawasan, Kepemimpinan Dan Kompensasi Terhadap Kinerja Pegawai Pada Badan Pengelola Keuangan Dan Barang Milik Daerah Kabupaten Minahasa Utara. Jurnal EMBA, 5(2), 1921-1928. 